ovil reaults, hare been noticed by observing men not belonging to the medical profession. Cobbett, in his Advice to Young Men, a work abounding with rich and excellent remarks upon the rearing and educating of children, observes: "The mind, as well as the body, requires time to come to its natural strength; and the way to have it possess at last its natural strength is not to attempt to load it too soon, and to favour it in its progress by giving to the body good and plentiful food, sweet air, and abundant exercise, accompanied with as little discontent and uneasiness as possible." Another popular writer says: "Knowledge should only keep pace with the natural growth of the human faculties. When I see a little urchin, who ought to be enjoying nature's holiday, and strengthening his constitution by wholesome exercise to bear the vicissitudes of the world in after times, kidnapped and sent to school, to sit on a bench for four or five hours together, employed in learning by rote what he is unable to comprehend, I cannot help contemplating him as the slave and the rictim of the ranity of the parent and the folly of the teacher. Such a system is only calculated to lay a foundation for disease and decrepitude, to stunt the physical and intellectual growth, and to produce a premature old age both in body and inind." The brain is the material organ by which all the mental faculties are manifested. In children, it is but partially developed; over excitement of it when in this state is extremely dangerous. For the guardians to send young girls from the union out into situations to be occupied in nursing and singing "lullaby" to a dirty little cross child in a garret, or "All in the Downs" in a scullery, after they have been taught singing, and studying geography, and occupied in tracing the map of Palestine, to enable them to study the Scriptures, is doing them a serious mental injury, and a moral wrong; it is trifling with their feelings, and is calculated to interfere with the functions of the brain in such a manner as to make them miserable and unhappy all their lifetime. When a member of the Board of Guardians, I recollect that application was made by the schoolmaster of the union for music paper to teach the children singing, and I was cruel enough to oppose the grant. I do not object to these poor young creatures singing the praise of God to the tune of the Old Hundredth, or Erening Hymn, but I think they should be able to do it without the notes. The Poor-Law Conmissioners never intended that the poor-rates should be appropriated to forming singing classes in the Union House, or be spent in decorating the walls of the schoolroom with maps.

The stuffing and over-cramming of the head of an unwilling and stubborn pauper boy with mental knowledge is not likely to make him more lively or contented in the position in life he is likely to be placed. But $I$ fear it is likely to produce a sadness and perverseness of disposition, which may and is likely to generate into a morbid state of the brain, which would in all probability end in insanity. To send such a boy out to be stuck on a seat from six in the morning till ten at night for seven years, to be kept in check by violence and fear, under the strict eyc of a disciplinarian tailor or shoemaker, who, because he is "only a pauper who nobody owns", think they may have their "pound of flesh" out of him, is a kind of treatment (after giving him almost a classical education) too much for a youthful mind to bear, and too much pressure on a vital organ just budding into maturity. This is cruel, and I consider criminal, on the part of those who stand in loco parentis. Their olject should be to make the children happy and contented when sent out into the world. This should be done by teaching them that that best fits their capacities, and to make them fully know and practise the business which belong to their stations. To create a taste and a craving for the grapes out of reach will never make them happy or contented.

A celebrated writer says: "Moral and religious training is of the first importance; other knowledge will take care of itself." Give them this impulse, it will manifest itself; let the pauper children be only thus instructed, and they
Fill be sure to find their way through the world, and will be happy and contented in whatever situation they may bo placed, and mental derangement and insanity prevented. The aim and object of pauper education ought to be to fit them for the sphere of life for which their studies and circumstances seemed to have intended them. Such emulation, encouraged in our union schools among the pauper children, must have a mischievous influence over their future prospects, instead of preparing them for domestic services, and to become useful members of society. A writer in one of our periodicals, in describing a young woman thus educated, says: "They marry, and know not how to keep their houses, how to cater,-no home comforts. The husband comes to an unclean house, a bad fire, an ill-dressed dinner; the wife has never learnt that first most necessary businesshow to cook. What is the consequence? The unsatisfied husband is put out of humour; he quits the house which has ceased to be a home. And where does he go ? Not far off is a public-house,-a clean room and sanded floor, etc., bright fire, and irresistible temptations. He meets others there like himself, driven out and tempted in, and the very first day makes him an incipient 'sot', and the sequel naturally is delirium tremens and insanity."

I have gone further into the question of education then I intended; and I fear I shall be suspected by the educationists of being opposed to education; but that is not the case. It is to the period when it ought to be begun, and the characters that are to be trained, and the effects on the physical and mental energies, to which I am opposed. It is to the taxing the brain before it is sufficiently consolidated, and its serious consequences, that I am most anxious to draw the nttention of the members of the Association; and I believe it is legitimately a medical question. "Order is IIeaven's first law ;" for the want of this, the best intentions and education may be rendered useless. If order, regularity, and punctuality were more rigidly enforced, and more practical teaching in our parochial and union schools, and less mental training, I believe there would be less crime and less insanity in the country.

Bath, July 1855.

\section{CASE OF POLYPUS OF THE UTERUS: REMOVAL BY LIGATURE: WITH REMARKS.}

By WII.LIAM WEBB, M.D., M.R.C.S.Eng., late HouseSurgeon to the Staffordshire General Infirmary.

PonyPI of the uterus are not infrequently met with among married females, as well as among those who have livea to the age of forty and upwards, and have led a life of celibacy; and, although cases somewhat analogous to the one I an about to record are to be found in the pages of the medical periodicals and elsewhere, nevertheless, as this case has interested me very much, it may not be entirely devoid of interest to other practitioners.

My partner, Mr. Cantrell, requested me to accompeny Mr. Fearn, of Derby, and himself, on Saturday, July 28th last, for the purpose of rendering assistance in the removal of one of these growths. He had been called to the case only a day or two before, and had only made one examination; and, although the substance closed pretty fully the cavity of the vagina as far as it reached, he felt satisfied that it had a pedicular attachment either to the os or the cervix uteri, and that its structure was of a fibrous character. The history of the case is as follows.

CAsE. Miss $H$., aged 47 , the sister of a farmer residing five miles from Wirksworth, a person of pale chlorotic appearance, and of leuco-phlegmatic temperament, had been suffering for upwards of seven years from a "dragging sensation" in the womb, some slight pain, and copious hæmorrhagic discharges recurring at very frequent periods; indeed, of late she had scarcely becn a day without much discharge. At the commencement of these symptoms, she consulted : surgeon, who told her that she was the subject of polypue, 
Wencencidered removal at that time nuadrisable. Since Whe had been trented by seven or eight different medicil men; and although, to use her orn language, "she had then gallons of medicine", she had failed, notwithstanding this very lengthened period of treatment, to obtain the relief the had so long expected. The last gleam of hope nor seemed almost to have vanished; she had ceased to consider that there was even a chance of complete recovery, or indeed of amelioration of the urgent symptoms which for ceven years past had made life a burthen to her. Her pulse was exceedingly feeble, and much accelerated; the muscular system was very flabby; in short, there was every indication of rapid sinking. Upon examination per vaginam, arm, smooth, and globular mass was felt closing the uterine part of the vagina, extending from the os to two and a half or three inches into the vaginal cavity, and evidently connected to the uterus by a pedicle, the precise attechment of which could not be distinguished. After a consultation, wo determined at once to pass a ligature round the pedicle, and allow the tumour to slough away. Mr. Cantrell accordingly introduced, by the aid of Gooch's canula, a piece of strong ligature twine, and succeeded in fixing it in the proper position. In tightening the ligature, it cut the pedicle through, and left the whole mass unattached in the vaginal cavity; thus saving the patient and ourselves no small amount of trouble and inconvenience. After several ineffectual attempts to remove it from its present situation by means of two fingers in the vagina and a third in the rectum, by the aid of polypus forceps, and by making incisions into its structure, we were obliged to return home (not having anticipated this favourable result) for other instruments. In the afternoon, we tried repeatedly, but without success, to remove it by the craniotomy forceps; and at last succeeded in delivering it by the rectis and left index finger. The polypus was of the size of a large orange, and nearly globular in shape. It was examined microscopically by my friend Mr. Moreton (the present house-surgeon of the Staffordshire Infirmary), by myself, and by others. I prefer to give the report obtained by Mr. Moreton from St. Thomas's Hospital, and prepared by Mr. Jones, the Lecturer on Comparative Anatomy. "Its structure, under the microscope, is fibro-cellular, and composed of very delicate undulating fibres, containing a few spherical cells within its meshes. On the addition of acetic acid, the structure seems to swell up, the fibrillation is rendered very indistinct, and numerous elongated nuclei become visible."

Although the hæmorrhage before the removal of the tumour had been such as to cause the utmost anxiety and fear, there was now scarcely any discharge at all; and the patient expressed herself as infinitely relieved, and far more comfortable than she had been for months past, notwithstanding the pain and soreness occasioned by the repeated use of instruments.

She was now directed to take as nutritious diet as her present impaired appetite would permit, and to have fire grains of compound soap and opium pill at bed-time.

July 29th. The patient stated that she had had a good night. She was very calm, and suffered but little pain. She had passed urine several times without difficulty since the operation. There was some slight heat of surface; the tongue was a little coated. She was directed to take an ounce of saline mixture every fourth hour.

August 2nd. She slept tolerably well since last report. There was very little fever, but great lack of appetite. The bowels were torpid. She was ordered to discontinue the saline, and to take a dose of castor oil, and the following mixture.

Bo Sodæ sesquicarbon. $3 \mathrm{j}$. Ammoniæ sesquicartion. $\exists j$ Infusi gentiana comp. Oss. M.

Fiat mistura, cujus sumat cochlearia duo magna bis terve in die.

August 10th. Since last report, the appetite had somewhat improved. She was able to take nome beef-tea, milk, and port wine; but the inconvenience of a large bronchocele prevented her from using much food in the solid atate. She was directed to discontinue the last medicine, and to take the following.

B Ferri-ammonio-tartratis 388 . Aquæ destillatæ Oss. M.

Fiat mistura, cujus sumat cochlearia duo magna bis terve in die.

August 27th. She continued to gain strength, but fancied the medicine did not agree with her. Her appetite was decidedly better. She was able to walk up and down stairs. She was ordered to continue the nutriment and port wine, and to take the following pills.

\section{R Ferri sulphatis $Э \mathrm{j}$.}

Extracti gentianæ $3 \mathrm{j}$. $\mathbf{M}$.

Fiant pilulæ $x x$, quarum sumat unam ter die.

It would be tedious, and would only take up space to no purpose, were I to continue my reports from day to day during the convalescence of the patient. It is sufficient now to add, that she is very much improved in health, strength, and general appearance; in fact, she would be perfectly well, were it not for the general debility consequent upon long continued hæmorrhage. She is persevering in the use of sulphate of iron; and I have little doubt but that, in two or three months, she will be restored to as good health as she enjoyed before the growth of the polypus commenced.

REMarks. The diagnosis in the above case was easily established by the previous history of our patient, and the examination per vaginam; but there were some difficulties when we came to consider the prognosis and appropriate treatment. Miss H. (at the best of times, I suspect, an exceedingly delicate person), was so much reduced by the continual drain, as to render the prognosis, under any system of treatment, a matter of very grave and serious import. Hence, there was no time to reflect upon the employment of palliative measures; and the only question which could possibly occur to us in commencing the treatment of such a case was, How, and by what means, can we most safely eradicate the fons et origo mali? Dr. Churchill goes so far as to say, that " if the polypus be within reach, nothing short of removal ought to be contemplated, as that alone will save the patient."* Believing in the propriety of removal, was this a case for the knife, for torsion, or for the ligature? With our present knowledge, it might not, and most probably would not have been attended with the slightest danger to use the knife or to employ torsion (perhaps the latter mode would have been the best); but knowing that these growths are sometimes largely supplied with blood-ressels, and being fearful of hæmorrhage, which, under existing circumstances, would have placed our patient in still more imminent peril, we at once decided to pass a ligature round the pedicle. I question whether this be not the safest proceeding with all pediculated tumours of this class; for should any unexpected hæmorrhage take place, the parts are out of sight, and the only expedients to which we can resort are the plug and the employment of styptics.

The difficulty experienced in the extraction of the mass from the vagina was partly owing to its size and shape (nearly globular) and partly to the contracted state of the vaginal cavity and os externum. Mr. Fearn mentioned a case to me in which he had similar difficulty.

At a discussion on this subject at the Smyrna MedicoChirurgical Society, on July 23rd, $\uparrow$ great good is said to have been effected in a case by the periodical application of leeches, and by small doses of the bichloride of mercury. Mr. Holthouse mentions, that this patient was first treated by Dr. Locock, and afterwards in Paris, where the system of leeching was pursued. It appesis aiso from the same report, that these tumours have sometimes disappeared of themselves, or become calcified. In a case, however, like the one which came under our notice, where the patient had been the subject of hæmorrhage for years, where me-

- Churchill's (Fleetwood, M.D.) Principal Diseases of Females, p. 199.

+ Medieal Times and Gazotio, Auguat 18th

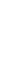


and tontent had been resorted to in rain, and that not anco only, but repeatedly, I am indeed sceptical of the proance onis, delaying the radical cure; for I believe that priety of delaying the radical cure; for I believe that nothing short of spoed red her that great amount of ease and comfort which she has ever since experienced.

Wirtsworth, Derbyehiro, Septombar 1855.

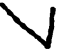

\section{ON CANCER.}

\section{By THOMAS POPE, Esq.}

Caxore, that crudele opprobium medicorum, will form the subject of this paper.

Of all the ills to which the human frame is liable, this is most poignant, and it has hitherto been considered incurable. From the idea of its incurability, I am happy to say that I dissent. What? Is an humble individual like myself to assert the curability of cancer? Yes, when the cause, the grand organ, is only functionslly diseased; but if the complaint organ, is only functionally diseased; but if the deranged, it is then, and only then, in my opinion, incurable. This may be considered tantamount to asserting not only the curability but the prerention of cancer. What a happy era will that be when it shall continue no longer a stigma medicorum, but be their captive, and ultimately annihilated! These are bold words; but, I hope, no less bold than true. Now let us come to close quarters with the enemy; let us see if we can discover its rise. Its progress and end we too painfully know.

It is a blood-disease, and, like all such, is generated within, and caused by a vitiated secretion of bile. What its peculiar nature is, we shall never attain to ; for who can tell what is the peculiar nature of the different skin-diseases and other disorders arising from contaminated blood? A greater refinement of chemistry may ultimately disclose much; but in our present state of knowledge, we know not how this or that peculiar blood disease is produced. This much I hsve reason to believe, that if the liver secrete a purely healthy bile, there can be no blood-disease internally generated, and, I had well nigh said, externally.

In my apprenticeship in the year 1797, my master and inoculated, in one day, upwards of three hundred of all ages, but mostly children. Their diet consisted of farinaceous and other vegetable productions, to the exclusion of all alcoholic drinks and animal food. The consequence was, that only one died, and from his own misconduct; for he infringed the rules both dietetically and medically; the others passed through the disorder according to the purity of the blood, or, in other words, according to the observance of the rules. Some few had it in the confluent form, but the majority had only two or three pustules; many had only one, and that at the place of the insertion of the virus; and five or six had the blood in so pure a state as to bid defiance to the poison, till they were allowed a more nutritious and stimulating diet. The medical part of the treatment consisted in a calomel pill repeated twice a week. The time of preparation was three weeks.

A few years ago, I vaccinated seven children of the same family. Fire took the infection the first time, the other two resisted; and though I repeated the insertion of the virus till the sixth time, with a week or fortnight's intermission, I could not succeed; but after a month's allowance of a rather generous diet, it took effect. Here I had every reason to believe that the purity of the blood was the cause of the success.

Cancer, gout, rheumatism, tubercle (shall I say cramp?), and all the various skin-diseases, arise from contaminated blood, and this contamination is the effect of a vitiated secretion of bile; so that to prevent impure blood, a watchful eye must be kept on the biliary secretion. When the liver is in a state of health the blood is pure, and health and strength are the happy consequences; but when its cecretion is deranged, this or that disorder will arise; and if the same canses that produce this derangement are con- tinued, the subetance of the liver becomes changed, and whatever be the disorder so produced, it is either fatal of Whatever be the disorder 80 produced, it its disorders which itself, or brings with it in graph it may not be amiss, for the prevention of hydrophobia to suggest the strictest attention, for some months, to the biliary secretion.

It may be asked, how is cancer formed? Before answering the question, I mean to confine myself to the description of scirrhus, to the exclusion of encephaloid cancer, and of fungus hrmatodes, which are alike fatal blooddiseases.

There is no part of the body exempt from the attacks of cancer, internally as well as externally; but it has proference for some parts more than others, as the breasts and uterus in females, the lips and genitals in man Its first appearance is in the form of a small hard knob, a deposit from the blood of the cancerous virus generated in the from the blood of the cancerous virus generated in the place of deposit is some injured part. How long it may place of deposit is somends altogether on the state of the liver as to its generation of the morbific matter. If that be suspended, and that may be for years, it is stationary; indeed I have known some who have lived to extreme old age in such a state, and who have not died thereof at last; so that its progress depends on the condition of the biliary secretion. As the poison is generated, so it is carried generally to its original place of deposit, whereby the knob enlarges. Now, the deposit is an effort of nature for the continuance of life; for if the poison were not eliminated from the system, death would soon ensue. This does not, at last, sypen from the poison in the system, but from its ravages in the part; for as the poison becomes more acrid, so the disorder progresses, till at last the scirrhus bursts, and becomes an open ulcer, with its horrid lancinating pains, and horrible and peculiar fotor.

At whatever stage of the disorder medical advice be had, the liver should be our polar star; and if that be only functionally affected, a cure may be hoped for: but if, on the contrary, it be organically affected, the only aid we can render is palliative. In tho former case, no progress will ensue, and it may be safely taken out; but in the latter, death will thereby be hastened.

As prevention is better than cure, another question may be asked, and that is, how is cancer prevented ? The natural corollary from the foregoing is to keep the liver healthy, and every worthy member of our Association recognises this state too well to need description.

A proper diet is of the first importance; but here let us remark, that as constitutions vary so much the diets do also; for the old saying may be here applied, "What is one man's meat is another's poison." The different temperaments roquire different diets, that of the scrofulous always generous. The urinary and alvine excretions should be diligently observed, because they are infallible guides. Nothing deranges the function of the liver more than grief, and this, of all the causes of cancer, is the most prolific; therefore it should always be avoided with the greatest care, especially as it leads to no good, and incapacitates us from properly meeting and overcoming its cause.

The next cause is constipation; and whatever disturbs the chylopoietic function, and excites a greater determination of blood to these parts; for the greater part of that blood has to pass through the liver in its return to the heart, so that if more be sent there than can be returned to the right auricle, the consequence is, that it is retarded in the liver, which becomes congested thereby, and, according to its congestion, so is the bile, and thus this secretion becomes vitiated. So that when the liver only receives that proportion of blood which can readily be returned to the heart, the bile is pure; and, e contraria parte, the longer the blood is congested therein, the more is it restricted, as wo all know that the bile is made from that blood which roturns by the vena porte to the heart, through the liver. Temperance, well regulated exercise, food easy of digestion, a contented and happy mind, and whatover conduces to a 